\title{
14. HYDROTHERMAL ALTERATION OF THE PERIDOTITES CORED AT THE OCEAN/CONTINENT BOUNDARY OF THE IBERIAN MARGIN: PETROLOGIC AND STABLE ISOTOPE EVIDENCE ${ }^{1}$
}

\author{
Pierre Agrinier, Laboratoire de Géochimie des Isotopes Stables, IPGP Université Paris VII, Paris, France \\ Catherine Mével, Laboratoire de Pétrologie Métamorphique, Université Paris VI, Paris, France \\ and \\ Jacques Girardeau, Laboratoire de Pétrologie Physique, IPGP Université Paris VII, Paris, France
}

\begin{abstract}
A ridge of strongly serpentinized, plagioclase-bearing peridotite crops out at the boundary between the Atlantic oceanic crust and the Galicia continental margin (western Spain). These peridotites, cored at Hole 637A (ODP Leg 103) have been mylonitized at high-temperature, low-pressure conditions and under large deviatoric stress during their uplift (Girardeau et al., this volume).

After this main ductile deformation event, the peridotite underwent a polyphase metamorphic static episode in the presence of water, with the crystallization of $\mathrm{Ti}$ - and $\mathrm{Cr}$-rich pargasites at high-temperature $\left(800^{\circ}-900^{\circ} \mathrm{C}\right)$ interaction with a metasomatic fluid or alkaline magma. Introduction of water produced destabilization of the pyroxenes and the subsequent development of hornblendes and tremolite at temperatures decreasing from $750^{\circ}$ to $350^{\circ} \mathrm{C}$. The main serpentinization of the peridotite occurred at a temperature below $300^{\circ} \mathrm{C}$, and possibly around $50^{\circ} \mathrm{C}$, as a consequence of the introduction of a large amount of seawater, which is suggested by stable isotope $\left(\delta^{18} \mathrm{O}\right.$ and $\left.\delta \mathrm{D}\right)$ data. Finally, calcite derived from seawater precipitated in late-formed fractures or locally pervasively impregnated the peridotite at low temperature $\left(\approx 10^{\circ} \mathrm{C}\right)$.
\end{abstract}

\section{INTRODUCTION}

Mantle peridotites crop out along the ocean/continent boundary of the Iberian continental margin, forming a 10-km-long continuous ridge. According to Boillot et al. (1980), they were emplaced during the first stages of the Atlantic Ocean opening. This ridge was cored at Site 637 during Ocean Drilling Program (ODP) Leg 103. The section of cored peridotite is about $70 \mathrm{~m}$ long and provides well-located samples from the upper part of the ocean floor. The samples are all strongly altered; they are almost completely serpentinized but also contain other hydrous phases such as amphibole, providing evidence of a polyphased history of interaction with a fluid.

The purpose of this paper is to retrace the alteration history of these rocks through petrological and stable isotope study of the secondary assemblages, that is, to determine when and at what temperature water penetrates and reacts to form secondary minerals. This should help in understanding the mechanism of emplacement of mantle peridotites in an opening rift, during the initial stages of ocean formation.

\section{SUMMARY OF THE MAIN LITHOLOGIC, STRUCTURAL, AND PETROLOGIC CHARACTERISTICS OF THE HOLE 637A PERIDOTITES}

A 70-m-thick peridotite section was cored at Hole 637A, near where these rocks crop out on the seafloor at the boundary between the Atlantic Ocean floor to the west and the Iberian continental margin to the east (Fig. 1). The peridotite section is homogeneous, displaying a well-marked foliation plane dipping at about $20^{\circ}$ with respect to horizontal in the first $50 \mathrm{~m}$ of the section and at about $70^{\circ}$ below that. At the top and base of the section (Cores 103-637A-23R and 103-637A-29R), the peridoti-

\footnotetext{
${ }^{1}$ Boillot, G., Winterer, E. L., et al., 1988. Proc. ODP, Sci. Results, 103: College Station, TX (Ocean Drilling Program).
}

tes are strongly brecciated and pervasively replaced by calcite. Massive serpentine fills fractures formed parallel or subperpendicular to the main foliation and, with calcite, is observed almost everywhere along the cored section. This gives most of the peridotite a yellow-brown color except in less fractured areas, where the peridotites are black.

Although the Hole 637A peridotites are intensively transformed into serpentine (generally to $90 \%$ ) or other secondary products, such as amphiboles, relicts of primary phases (particularly orthopyroxene, clinopyroxene, and spinel) are usually still present. Olivine is very rare and was found only in a few samples. Plagioclase is locally abundant (a few percent) rimming spinel or forming isolated, discontinuous thin veins. Considering their modal composition, the peridotites are spinel or spinel and plagioclase harzburgites or lherzolites. They are locally enriched or depleted in orthopyroxene, and some display clinopyroxene lenses, a few millimeters thick and several centimeters long. Temperatures of equilibration of $960^{\circ}$ to $1100^{\circ} \mathrm{C}$ have been estimated from the peridotite primary assemblage (Boillot et al., 1980; Girardeau et al., this volume; Kornprobst and Talbit, this volume; Evans and Girardeau, this volume).

The "primary" high-temperature tectonic structures of the Hole 637A peridotites are perfectly preserved, except in the calcite-rich samples. The peridotites appear strongly deformed, showing evidence of intense stretching. They have recrystallized at various degrees along shear bands crosscutting the primary foliation. From textural and petrological analyses of the primary phases, Girardeau et al. (this volume) concluded that the peridotite underwent a high-strain $(\gamma \approx 12)$-high-stress $(\approx 180$ $\mathrm{MPa}$ ) ductile deformation event, at a temperature decreasing from $1000^{\circ}$ to $850^{\circ} \mathrm{C}$ and a pressure down to $0.2 \mathrm{GPa}$, possibly in hydrous conditions.

The peridotites do not display any moderate- to low-deformation structures that could be related to their final emplacement, except for some fracturing. This raises the problem of the serpentinization event, which could have occurred in subsurface conditions or could represent a deeper and earlier phenomenon. 


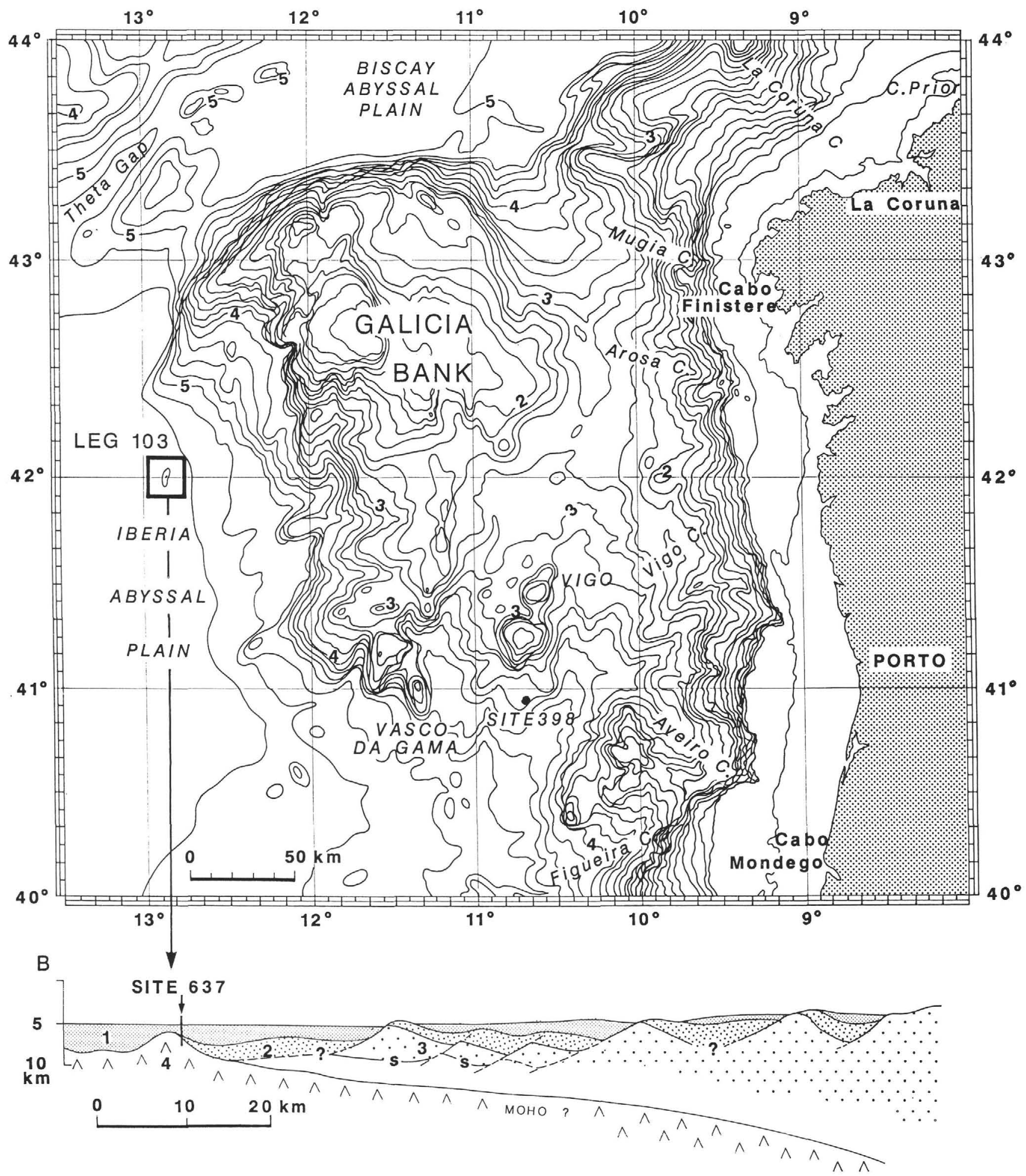

Figure 1. Bathymetric map (A) and synthetic cross section (B) showing the location of Hole 637A peridotites drilled during ODP Leg 103 at the boundary between the oceanic domain and Galicia. 1 = post-rift sediments; 2 = syn-rift sediments; $3=$ continental basement; $4=$ serpentinized peridotite; $\mathrm{S}=\mathrm{S}$ seismic reflector (from Boillot et al., this volume).

\section{TEXTURE AND CHEMISTRY OF SECONDARY PHASES}

All samples are extensively serpentinized. In increasing order of resistance to alteration are plagioclase and olivine, orthopyroxene, clinopyroxene, and finally spinel, which appears com- pletely preserved. Serpentinization occurred under static conditions, as evidenced by the preservation of most details of the original rock texture. Most samples consist predominantly of mesh texture serpentine plus magnetite replacing olivine. Pyroxene crystals are replaced by fibrous serpentine, bastite, which preserves their initial shapes. For instance, the elongate shape of 
orthophyroxene porphyroclasts remains obvious even when completely replaced by bastite (Pl. 1, Fig. 1). Talc may occur in orthopyroxene pseudomorphs, either interbanded with serpentine or as an outer rim (Pl. 1, Fig. 2). Serpentine also fills narrow veins (sometimes up to $1 \mathrm{~cm}$ thick). The most striking character of these peridotites is the relative abundance of amphiboles, showing various textures, as will be discussed subsequently. Finally, large calcite veins, postdating all the other secondary phases, locally crosscut the rocks. In some cases calcite also occurs in mineral pseudomorphs, for example, in the center of serpentine cells.

Some of the secondary minerals, mostly amphiboles and serpentine, were analyzed with a microprobe in order to determine their chemistry and conditions of formation. Analyses were performed with a CAMEBAX microprobe (Camparis, Université Pierre et Marie Curie) using a combination of oxides and natural minerals as standards. The accelerating voltage was $15 \mathrm{kV}$, the beam current $20 \mathrm{~mA}$, and the counting time varied between 10 and $20 \mathrm{~s}$, depending on the elements. A disfocused beam was used for serpentine and talc crystals.

\section{Amphiboles}

Although amphiboles have been described in some oceanic serpentinites (Aumento and Loubat, 1971; Kimball et al., 1985), they generally are not common in this type of rock, and most serpentinites are completely devoid of amphiboles (Prichard, 1979; Michael and Bonatti, 1985). In the Hole 637A serpentinites, amphibole is not only abundant but displays a large variety of textures corresponding to a wide range in composition.

Large, isolated crystals of pale brown-green amphiboles (up to $200 \mu \mathrm{m}$ in width) are associated with clinopyroxene pseudomorphs (Pl. 1, Fig. 3). Smaller elongated crystals are much more abundant and are commonly concentrated at the periphery of the orthopyroxene pseudomorphs. In Sample 103-637A$26 \mathrm{R}-4,67-69 \mathrm{~cm}$, amphibole penetrates inside the pyroxene along cleavages (Pl. 1, Fig. 4). Such a texture recalls clinopyroxene exsolution in orthopyroxene (as illustrated in Aumento and Loubat, 1971), and amphibole has likely replaced exsolved clinopyroxene. In Sample 103-637A-37R-2, 20-26 cm, large needles of colorless amphiboles have grown on a spinel grain (Pl. 1, Fig. 5). Amphibole occurs most commonly as intergrown colorless needles, commonly aligned in bands or veins as if replacing a previous elongated phase (pyroxene?) (Pl. 1, Fig. 6).

The growth of amphiboles is never related to a deformation event and they all appear to have formed under static conditions. Microprobe analyses show that all of the amphiboles are calcic. Their structural formulas were calculated on 23 oxygens, considering all iron as ferrous (Table 1$). \mathrm{An} \mathrm{Al}^{\mathrm{IV}}$ vs. $(\mathrm{Na}+\mathrm{K})$ diagram plots in two dense groups, with scattered points between the two, close to a trend typing pargasite and tremolite (Fig. 2A).

The most tabular crystals are pargasite. These are particularly abundant in Sample 103-637A-26R-4, 67-69 cm, where they surround and penetrate orthopyroxene crystals. Pargasite forms some small crystals in other samples. They are always iron poor (2-3 wt\%) and contain appreciable amounts of chromium (1.5-2.3 wt\% $\mathrm{Cr}_{2} \mathrm{O}_{3}$ ) and titanium (1.5-3.3 wt\% $\mathrm{TiO}_{2}$ ). Representative analyses are relatively scattered in a $\mathrm{Cr}$ vs. $\mathrm{Ti}$ diagram (Fig. 2B). The chromium content is constant, but the titanium content is differentiated into two groups, one low in titanium (Sample 103-637A-26R-4, 67-69 cm) and another much enriched in that element, corresponding to all of the other samples. The potassium content is always low $\left(<0.1 \mathrm{wt} \% \mathrm{~K}_{2} \mathrm{O}\right)$, except in Sample 103-637A-27R-5, 48-50 cm, where titanium-rich pargasites contain $0.4 \mathrm{wt} \% \mathrm{~K}_{2} \mathrm{O}$. All pargasites have chlorine below detection.
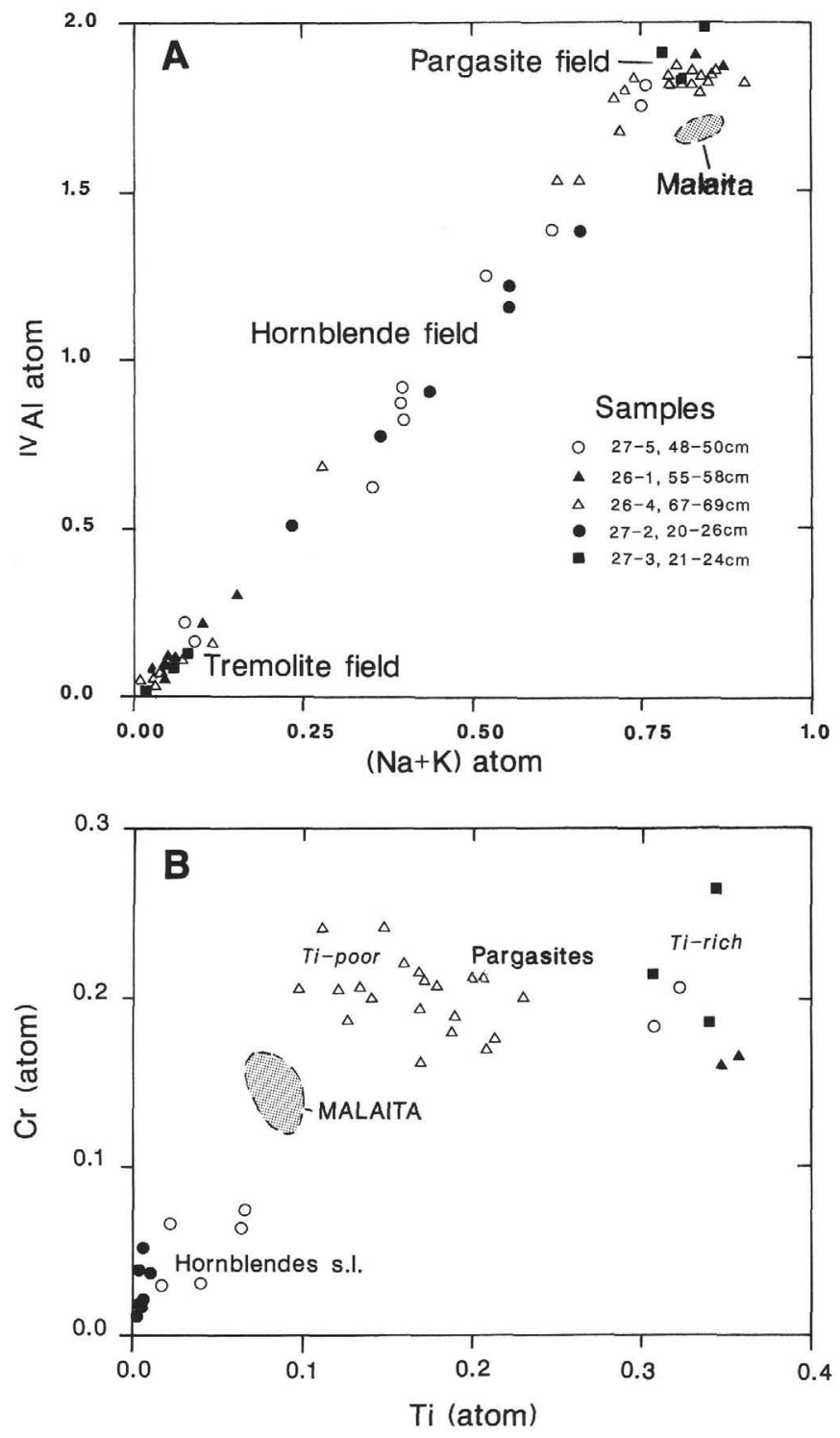

Figure 2. Amphibole compositions. A. $\mathrm{A} 1^{\mathrm{IV}}$ vs. $(\mathrm{Na}+\mathrm{K}$ of Hole $627 \mathrm{~A}$ samples). The field within the dotted line corresponds to the amphibole from oceanic peridotites (Malaita xenoliths, unpubl. data). B. Cr/Ti for pargasites.

Intermediate compositions corresponding to hornblendes s.l. are less common. They are not particularly associated with pyroxenes, and the best example is the large needles that have grown on a spinel grain in Sample 103-637A-27R-2, 20-26 cm. Figure $2 \mathrm{~B}$ shows that they contain small amounts of titanium and chromium, are postassium poor, and may contain up to 0.2 wt $\%$ chlorine.

Tremolite compositions correspond to fibrous colorless needles. Their iron content is very low $(2-3 \mathrm{wt} \%)$.

\section{Serpentine and Talc}

$\mathrm{X}$-ray diffraction (XRD) patterns obtained on bulk samples confirm the shipboard results: serpentine is either lizardite or chrysotile, and no antigorite was detected. Representative analyses of serpentines are listed in Table 2.

Serpentine occurs in two major microstructural sites: after pyroxene (bastite) and after olivine (mesh texture). It also occurs 
Table 1. Representative analyses of amphiboles.

\begin{tabular}{|c|c|c|c|c|c|c|c|c|c|c|c|c|}
\hline & \multirow{2}{*}{\multicolumn{2}{|c|}{$\begin{array}{c}103-637 \mathrm{~A}-26 \mathrm{R}-1, \\
55-58 \mathrm{~cm}\end{array}$}} & \multicolumn{4}{|c|}{ 103-637A-26R-4, 67-69 cm } & \multirow{3}{*}{$\begin{array}{c}\begin{array}{c}103-637 A- \\
27 R-2, \\
20-26 \mathrm{~cm}\end{array} \\
\text { Hornblende }\end{array}$} & \multirow{2}{*}{\multicolumn{2}{|c|}{$\begin{array}{c}\text { 103-637A-27R-3, } \\
21-24 \mathrm{~cm}\end{array}$}} & \multirow{2}{*}{\multicolumn{3}{|c|}{$\begin{array}{c}103-637 \mathrm{~A}-27 \mathrm{R}-5 \\
48-50 \mathrm{~cm}\end{array}$}} \\
\hline & & & \multirow{2}{*}{$\begin{array}{c}\text { Large } \\
\text { individual } \\
\text { pargasite } \\
\text { crystal }\end{array}$} & \multirow[b]{2}{*}{$\begin{array}{c}\text { Tabular } \\
\text { pargasite }\end{array}$} & \multirow{2}{*}{$\begin{array}{c}\text { Pargasite } \\
\text { after } \\
\text { clinopyroxene } \\
\text { exsolution }\end{array}$} & \multirow[b]{2}{*}{$\begin{array}{l}\text { Fibrous } \\
\text { tremolite }\end{array}$} & & & & & & \\
\hline & $\begin{array}{c}\text { Tabular } \\
\text { pargasite }\end{array}$ & $\begin{array}{l}\text { Fibrous } \\
\text { tremolite }\end{array}$ & & & & & & $\begin{array}{c}\text { Tabular } \\
\text { pargasite }\end{array}$ & Tremolite & $\begin{array}{c}\text { Tabular } \\
\text { pargasite }\end{array}$ & Hornblende & Tremolite \\
\hline $\mathrm{SiO}_{2}$ & 42.94 & 58.05 & 43.53 & 43.94 & 43.75 & 58.21 & 50.97 & 42.76 & 57.51 & 44.17 & 51.75 & 57.72 \\
\hline $\mathrm{Ti}_{2}$ & 3.35 & 0.09 & 1.51 & 2.18 & 1.58 & 0.06 & 0.04 & 3.20 & 0.07 & 3.06 & 0.16 & 0.00 \\
\hline $\mathrm{Al}_{2} \mathrm{O}_{3}$ & 14.28 & 1.09 & 15.09 & 14.32 & 14.83 & 0.48 & 8.02 & 14.19 & 0.59 & 13.75 & 6.91 & 1.34 \\
\hline $\mathrm{Cr}_{2} \mathrm{O}_{3}$ & 1.51 & 0.05 & 1.96 & 1.82 & 1.73 & 0.12 & 0.23 & 2.36 & 0.02 & 2.06 & 0.28 & 0.00 \\
\hline $\mathrm{FeO}$ & 3.19 & 1.85 & 3.11 & 2.84 & 2.78 & 2.33 & 2.57 & 3.19 & 2.37 & 2.93 & 2.33 & 1.57 \\
\hline $\mathrm{MnO}$ & 0.00 & 0.04 & 0.02 & 0.05 & 0.05 & 0.06 & 0.03 & 0.00 & 0.05 & 0.06 & 0.15 & 0.11 \\
\hline $\mathrm{MgO}$ & 16.77 & 23.32 & 17.25 & 17.72 & 17.20 & 23.22 & 20.64 & 16.34 & 22.46 & 17.72 & 20.20 & 24.39 \\
\hline $\mathrm{NiO}$ & 0.12 & 0.02 & 0.00 & 0.11 & 0.00 & 0.03 & 0.08 & 0.00 & 0.00 & 0.00 & 0.00 & 0.00 \\
\hline $\mathrm{CaO}$ & 12.55 & 13.68 & 11.69 & 12.30 & 12.08 & 13.51 & 13.18 & 12.16 & 13.15 & 11.36 & 12.12 & 12.63 \\
\hline $\mathrm{Na}_{2} \mathrm{O}$ & 3.23 & 0.21 & 2.77 & 3.08 & 3.43 & 0.20 & 1.59 & 3.65 & 0.27 & 3.45 & 1.23 & 0.27 \\
\hline $\mathrm{K}_{2} \mathrm{O}$ & 0.14 & 0.02 & 0.03 & 0.02 & 0.03 & 0.00 & 0.03 & 0.05 & 0.01 & 0.38 & 0.02 & 0.00 \\
\hline $\mathrm{Cl}$ & 0.00 & 0.00 & 0.00 & 0.00 & 0.00 & 0.00 & 0.12 & 0.00 & 0.00 & 0.00 & 0.00 & 0.00 \\
\hline Total & 98.08 & 98.42 & 97.96 & 98.38 & 97.46 & 98.22 & 97.47 & 97.90 & 96.51 & 98.94 & 97.15 & 98.03 \\
\hline \multicolumn{13}{|c|}{ Structural formulas ( 23 oxygens) } \\
\hline $\mathrm{Si}$ & 6.081 & 7.879 & 6.147 & 6.172 & 6.194 & 7.931 & 7.099 & 6.076 & 7.966 & 6.180 & 7.185 & 7.838 \\
\hline $\mathrm{Al}^{\mathrm{IV}}$ & 1.919 & 0.121 & 1.853 & 1.828 & 1.806 & 0.069 & 0.901 & 1.924 & 0.034 & 1.820 & 0.815 & 0.162 \\
\hline $\mathrm{Al}^{\mathrm{VI}}$ & 0.466 & 0.053 & 0.659 & 0.544 & 0.670 & 0.008 & 0.416 & 0.454 & 0.062 & 0.449 & 0.316 & 0.053 \\
\hline $\mathrm{Ti}$ & 0.357 & 0.009 & 0.160 & 0.230 & 0.168 & 0.006 & 0.004 & 0.342 & 0.007 & 0.322 & 0.017 & 0.000 \\
\hline $\mathrm{Cr}$ & 0.169 & 0.005 & 0.219 & 0.202 & 0.194 & 0.013 & 0.025 & 0.265 & 0.002 & 0.228 & 0.031 & 0.000 \\
\hline $\mathrm{Fe}$ & 0.378 & 0.210 & 0.368 & 0.334 & 0.330 & 0.266 & 0.299 & 0.379 & 0.275 & 0.343 & 0.271 & 0.178 \\
\hline $\mathrm{Mn}$ & 0.000 & 0.005 & 0.002 & 0.006 & 0.006 & 0.007 & 0.004 & 0.000 & 0.006 & 0.007 & 0.018 & 0.013 \\
\hline $\mathrm{Mg}$ & 3.540 & 4.715 & 3.594 & 3.672 & 3.631 & 4.697 & 4.243 & 3.461 & 4.637 & 3.651 & 4.348 & 4.756 \\
\hline $\mathrm{Ni}$ & 0.014 & 0.012 & 0.000 & 0.012 & 0.000 & 0.003 & 0.009 & 0.000 & 0.000 & 0.000 & 0.000 & 0.000 \\
\hline $\mathrm{MgM}_{4}$ & 0.000 & 0.003 & 0.039 & 0.038 & 0.000 & 0.019 & 0.042 & 0.000 & 0.000 & 0.044 & 0.246 & 0.181 \\
\hline $\mathrm{Ca}$ & 1.905 & 1.990 & 1.769 & 1.852 & 1.830 & 1.973 & 1.967 & 1.852 & 1.952 & 1.703 & 1.803 & 1.838 \\
\hline $\mathrm{NaM}_{4}$ & 0.095 & 0.007 & 0.192 & 0.110 & 0.170 & 0.009 & 0.000 & 0.148 & 0.048 & 0.252 & 0.000 & 0.000 \\
\hline $\mathrm{NaA}$ & 0.792 & 0.048 & 0.841 & 0.729 & 0.771 & 0.044 & 0.429 & 0.858 & 0.024 & 0.684 & 0.331 & 0.071 \\
\hline $\mathbf{K}$ & 0.025 & 0.003 & 0.005 & 0.004 & 0.005 & 0.000 & 0.005 & 0.009 & 0.002 & 0.068 & 0.004 & 0.000 \\
\hline Total & 15.817 & 15.051 & 15.846 & 15.732 & 15.777 & 15.044 & 15.435 & 15.867 & 15.026 & 15.752 & 15.385 & 15.090 \\
\hline
\end{tabular}

in veins or around spinel or amphibole crystals. Figure 3 shows that serpentine composition is strongly influenced by the chemistry of the mineral it replaces. Serpentine after orthopyroxene is consistently enriched in aluminum with respect to serpentine after olivine, for similar iron contents. This suggests that aluminum is immobile during serpentinization and remains in the orthopyroxene site (Bonatti and Hamlyn, 1981). Some exceptionally $\mathrm{Al}$-rich (up to $12 \mathrm{wt} \% \mathrm{Al}_{2} \mathrm{O}_{3}$ ) phyllites occur in pseudomorphs from Sample 103-637A-26R-4, 67-69 cm. These might correspond to a mixture with chlorite or to talc-chlorite.

In primary assemblages, chromium enters pyroxenes (other than spinel) and nickel enters olivine. Michael and Bonatti (1985) have already noted that chromium enters bastite, and they used the chromium content of bastite to discriminate between orthopyroxene and clinopyroxene pseudomorphs. In this case, it is also clear that chromium does not migrate during serpentinization and remains in the pyroxene sites. Serpentine from orthopyroxene pseudomorphs commonly contains between 0.4 and 0.6 wt $\% \mathrm{Cr}_{2} \mathrm{O}_{3}$, which is the average content of orthopyroxene, whereas serpentine after olivine is completely devoid of chromium. However, the case of nickel is different. Small amounts of nickel $(0.2$ to $0.4 \mathrm{wt} \% \mathrm{NiO})$ are present in serpentine after both olivine and orthopyroxene, although the latter does not contain nickel. Nickel is therefore mobilized and redistributed in the whole rock during serpentinization. This is also evidenced by the presence of scattered secondary nickel and iron sulfides.

Serpentine may contain appreciable amounts of chlorine. A histogram of chlorine (Fig. 3) shows a wide range of values, up to an isolated maximum of $0.9 \mathrm{wt} \% \mathrm{Cl}$. It is not known how chlorine enters the lattice structure of serpentine. Rucklidge and Patterson (1977) suggested that chlorine is present in the form of submicroscopic grains of the compound $\mathrm{Fe}_{2}(\mathrm{OH})_{3}$ in the altered dunites that they studied, whereas in other cases chlorine is thought to replace $\left(\mathrm{OH}^{-}\right)$in the serpentine structure (Ruck- lidge, 1972). Although the samples come from a submarine environment, it is clear that these values do not correspond to $\mathrm{NaCl}$ precipitates from seawater because $\mathrm{Na}_{2} \mathrm{O}$ is always very low $(<0.05 \mathrm{wt} \%)$ and does not correlate with chlorine. The chlorine content shows no relation with the serpentine texture. Appreciable amounts of chlorine have been measured in other oceanic serpentines: up to $0.5 \mathrm{wt} \%$ in serpentines from the Gorringe Bank (about $300 \mathrm{~km}$ south of the Galicia Bank) and up to $0.4 \mathrm{wt} \%$ in serpentines from Deep Sea Drilling Project (DSDP) Hole 556 (C. Mével, unpubl. data). Further studies are necessary to determine how chlorine enters serpentine, but its presence in serpentinites must be emphasized because it may influence the chemical budget of chlorine in the ocean and play a role in subduction zones.

Talc occurs only in orthopyroxene pseudomorphs. It contains about $3 \mathrm{wt} \%$ of $\mathrm{Al}_{2} \mathrm{O}_{3}, 2 \mathrm{wt} \% \mathrm{FeO}$, and appreciable chromium $\left(0.3-0.6 \mathrm{wt} \% \mathrm{Cr}_{2} \mathrm{O}_{3}\right)$, again demonstrating the immobility of this element.

\section{PETROLOGIC IMPLICATIONS: DISCUSSION ON THE ORIGIN OF THE HYDROUS PHASES}

The nature and composition of secondary phases found in the Hole 637A peridotites imply a polyphase history. The serpentine species present in the rocks (lizardite and chrysotile) are the low-temperature varieties (Wenner and Taylor, 1971; Evans et al., 1976; Moody, 1976). However, the presence of antigorite in Hole 637A peridotites cannot be ruled out. In the Gorringe Bank sepentinites, antigorite is present and concentrated in shear zones (Prichard, 1979). Such late shear zones were not observed in Hole 637A, but we cannot exclude that they were lost during the drilling process, considering that only $39 \mathrm{~m}$ of rock was recovered from the $70-\mathrm{m}$-long cored section. The presence of lizardite and chrysotile indicates that most of the serpentinization process occurred at temperatures below $300^{\circ} \mathrm{C}$. On the 
Table 2. Representative analyses of serpentines. Structural formulas are calculated on the basis of 7 oxygens, execpt for talc-chlorite analysis (28 oxygens).

\begin{tabular}{|c|c|c|c|c|c|c|c|c|c|}
\hline \multirow[b]{2}{*}{ Sample } & \multicolumn{2}{|c|}{$103-637 \mathrm{~A}-26 \mathrm{R}-1,55-58 \mathrm{~cm}$} & \multicolumn{3}{|c|}{$103-637 \mathrm{~A}-26 \mathrm{R}-4,67-69 \mathrm{~cm}$} & \multicolumn{2}{|c|}{$103-637 \mathrm{~A}-27 \mathrm{R}-2,20-26 \mathrm{~cm}$} & \multicolumn{2}{|c|}{$103-637 \mathrm{~A}-27 \mathrm{R}-5,48-50 \mathrm{~cm}$} \\
\hline & $\begin{array}{c}\text { Serpentine after } \\
\text { orthopyroxene }\end{array}$ & $\begin{array}{l}\text { Serpentine } \\
\text { after olivine }\end{array}$ & $\begin{array}{l}\text { Serpentine after } \\
\text { orthopyroxene }\end{array}$ & $\begin{array}{c}\text { Serpentine } \\
\text { after olivine }\end{array}$ & Talc-chlorite(?) & $\begin{array}{c}\text { Serpentine } \\
\text { after olivine }\end{array}$ & $\begin{array}{c}\text { Serpentine after } \\
\text { orthopyroxene }\end{array}$ & $\begin{array}{l}\text { Serpentine } \\
\text { after olivine }\end{array}$ & $\begin{array}{c}\text { Serpentine after } \\
\text { orthopyroxene }\end{array}$ \\
\hline $\mathrm{SiO}_{2}$ & 40.58 & 42.88 & 42.07 & 42.19 & 37.94 & 41.39 & 42.62 & 39.39 & 38.70 \\
\hline $\mathrm{TiO}_{2}$ & 0.03 & 0.03 & 0.09 & 0.01 & 0.15 & 0.00 & 0.04 & 0.00 & 0.08 \\
\hline $\mathrm{AL}_{2} \mathrm{O}_{3}$ & 5.38 & 0.13 & 2.63 & 0.01 & 11.28 & 0.00 & 3.71 & 0.11 & 2.60 \\
\hline $\mathrm{Cr}_{2} \mathrm{O}_{3}$ & 0.46 & 0.00 & 0.64 & 0.04 & 0.90 & 0.00 & 0.60 & 0.03 & 0.91 \\
\hline $\mathrm{FeO}^{3}$ & 6.28 & 5.61 & 4.69 & 4.85 & 2.50 & 4.24 & 4.77 & 5.40 & 5.31 \\
\hline $\mathrm{MnO}$ & 0.04 & 0.01 & 0.08 & 0.00 & 0.00 & 0.04 & 0.05 & 0.08 & 0.07 \\
\hline $\mathrm{MgO}$ & 28.73 & 37.35 & 36.89 & 39.40 & 34.50 & 37.28 & 35.07 & 38.35 & 35.58 \\
\hline $\mathrm{NiO}$ & 0.32 & 0.43 & 0.10 & 0.24 & 0.14 & 0.15 & 0.08 & n.d. & n.d. \\
\hline $\mathrm{CaO}$ & 0.59 & 0.21 & 0.01 & 0.02 & 0.04 & 0.05 & 0.07 & 0.03 & 0.03 \\
\hline $\mathrm{Na}_{2} \mathrm{O}$ & 0.05 & 0.04 & 0.01 & 0.00 & 0.04 & 0.03 & 0.07 & 0.00 & 0.00 \\
\hline $\mathrm{K}_{2} \mathrm{O}$ & 0.11 & 0.00 & 0.00 & 0.00 & 0.00 & 0.01 & 0.01 & 0.01 & 0.01 \\
\hline $\mathrm{Cl}$ & 0.04 & 0.07 & 0.06 & 0.16 & 0.01 & 0.19 & 0.13 & n.d. & n.d. \\
\hline Total & 82.61 & 86.76 & 87.27 & 86.92 & 87.50 & 83.38 & 87.22 & 83.39 & 83.29 \\
\hline $\mathrm{Cl}=0$ & 0.01 & 0.02 & 0.01 & 0.04 & 0.00 & 0.04 & 0.03 & - & - \\
\hline Total $-\mathrm{Cl}$ & 82.60 & 86.74 & 87.26 & 86.92 & 87.50 & 83.34 & 87.19 & 83.39 & - \\
\hline $\mathrm{Si}$ & 2.023 & 2.042 & 1.980 & 2.003 & 7.043 & 2.038 & 2.001 & 1.958 & 1.924 \\
\hline $\mathrm{Ti}$ & 0.001 & 0.001 & 0.003 & 0.000 & 0.021 & 0.000 & 0.001 & 0.000 & 0.003 \\
\hline $\mathrm{Al}$ & 0.316 & 0.007 & 0.146 & 0.001 & 1.944 & 0.000 & 0.205 & 0.006 & 0.153 \\
\hline $\mathrm{Cr}$ & 0.018 & 0.000 & 0.024 & 0.002 & 0.132 & 0.000 & 0.022 & 0.001 & 0.036 \\
\hline $\mathrm{Fe}$ & 0.262 & 0.223 & 0.185 & 0.193 & 0.388 & 0.175 & 0.187 & 0.225 & 0.221 \\
\hline $\mathrm{Mn}$ & 0.002 & 0.000 & 0.003 & 0.000 & 0.000 & 0.002 & 0.002 & 0.003 & 0.003 \\
\hline $\mathrm{Mg}$ & 2.135 & 2.651 & 2.587 & 2.788 & 9.546 & 2.737 & 2.454 & 2.843 & 2.637 \\
\hline $\mathrm{Ni}$ & 0.013 & 0.016 & 0.004 & 0.009 & 0.021 & 0.006 & 0.003 & - & - \\
\hline $\mathrm{Ca}$ & 0.032 & 0.011 & 0.001 & 0.001 & 0.008 & 0.003 & 0.004 & 0.002 & 0.002 \\
\hline $\mathrm{Na}$ & 0.005 & 0.004 & 0.001 & 0.000 & 0.014 & 0.003 & 0.006 & 0.000 & 0.000 \\
\hline $\mathbf{K}$ & 0.007 & 0.000 & 0.000 & 0.000 & 0.000 & 0.001 & 0.001 & 0.000 & 0.001 \\
\hline Total & 4.814 & 4.955 & 4.933 & 4.996 & $\overline{19.643}$ & $\overline{4.963}$ & 4.887 & 5.038 & 4.979 \\
\hline $\mathrm{Cl}$ & 0.003 & 0.006 & 0.001 & 0.013 & 0.003 & 0.016 & 0.010 & - & - \\
\hline
\end{tabular}

Note: n.d. = not detected.

other hand, amphiboles, and particularly the pargasites, reflect much higher temperatures of alteration.

Jenkins (1983) discussed the stability of calcic amphiboles in ultramafic rocks. He showed that tremolite is stable up to $750^{\circ} \mathrm{C}$ and becomes progressively enriched in aluminum up to pargasite, which breaks down around $1050^{\circ} \mathrm{C}$. Iron lowers these temperatures (Gilbert, 1966), but in the Hole 637A peridotite samples, the $\mathrm{Mg} /(\mathrm{Mg}+\mathrm{Fe})$ ratio is always very high (0.9). These results suggest that pargasite formed at very high temperatures, probably between $800^{\circ}$ and $900^{\circ} \mathrm{C}$.

Primary mantle-derived pargasite and Ti-pargasite are known in lherzolite xenoliths from the continental environment (Dawson and Smith, 1982). Such amphiboles are also present in a number of peridotite massifs, such as Finero, Ronda, and Lherz, and, here again, are considered as primary mantle features. Pargasites seem to be scarce in peridotites from oceanic environments, but this probably results from the limited sampling. However, such amphiboles have been long known in St. Paul's rocks peridotites (Melson et al., 1967, 1972), occurring as a primary phase in amphibole-bearing peridotites interpreted as derived from pyroxene-rich peridotites by a reaction involving clinopyroxene and water at high temperature. The peridotites have been mylonitized during their emplacement, and secondary pargasitic hornblende formed locally after the mylonitization. The titanium content of St. Paul's rocks pargasites is similar to that measured in Hole 637A peridotite pargasites. Unfortunately, chromium was not analyzed in St. Paul's rocks peridotite, which makes comparison difficult. Kimberlites have also been sampled from the Pacific Ocean mantle at Malaita Island of the Salomon Archipelago. The mantel xenoliths are lherzolites in which light brown amphiboles occur as a primary phase (Mixon and Coleman, 1978; Bertrand and Mercier, 1983). The amphiboles either rim primary Cr-rich diopside or constitute isolated crystals. They are Ti- and Cr-rich pargasite hornblendes similar to the Hole 637A pargasites. Abundant Ti- and Cr-rich pargasite also occurs in Zabargad Island (Red Sea) peridotites (Bonatti et al., 1986) and is thought to be emplaced during the first stage of ocean formation, similar to the Hole 637A peridotites (Bonatti et al., 1981; Nicolas and Boudier, 1987). These amphiboles are interpreted as resulting from the reaction of metasomatic fluids with spinel lherzolites in the upper mantle (Bonatti et al., 1986).

In the Hole 637A peridotites, some amphiboles obviously formed by reaction between clinopyroxene and a hydrous fluid phase (Pl. 1, Fig. 5). Others (Pl. 1, Figs. 3 and 4) seem to have formed independently. Because of the strong serpentinization of all the samples, it is difficult to interpret the textures. However, we suggest that $\mathrm{Ti}$ - and $\mathrm{Cr}$-rich pargasite formed at very high temperatures $\left(800^{\circ}-900^{\circ} \mathrm{C}\right)$ in the mantle from interaction with metasomatic fluid and/or possibly from a magma percolating in the peridotites. The chromium content of pargasites may be inherited from the clinopyroxene. But the titanium content (up to $3 \%$ ) is too high and requires an external source, which could be either the metasomatic fluid or the magma. It should be pointed out, however, that the potassium content of pargasites from the Hole 637A peridotites is very low. This suggests that if metasomatism occurred, the fluid was not potassic, as opposed to St. Paul's rocks, in which phlogopite is associated with pargasites.

Pargasites formed under mantle conditions are in two examples of opening-rift peridotites: a present-day form at Zabargad Island and a fossil occurrence at Site 637 (this study). Although we have observed that pargasites generally do not occur in oceanic peridotites from other environments (Aumento and Loubat, 1971; Kimball et al., 1985), they are known in St. Paul's rocks. This particular geodynamic setting of a rift opening between two continents might explain the metasomatism, but other examples are necessary to verify this assumption.

Hornblendes and tremolites are more common in oceanic peridotites. They are stable under lower temperature, amphibo- 

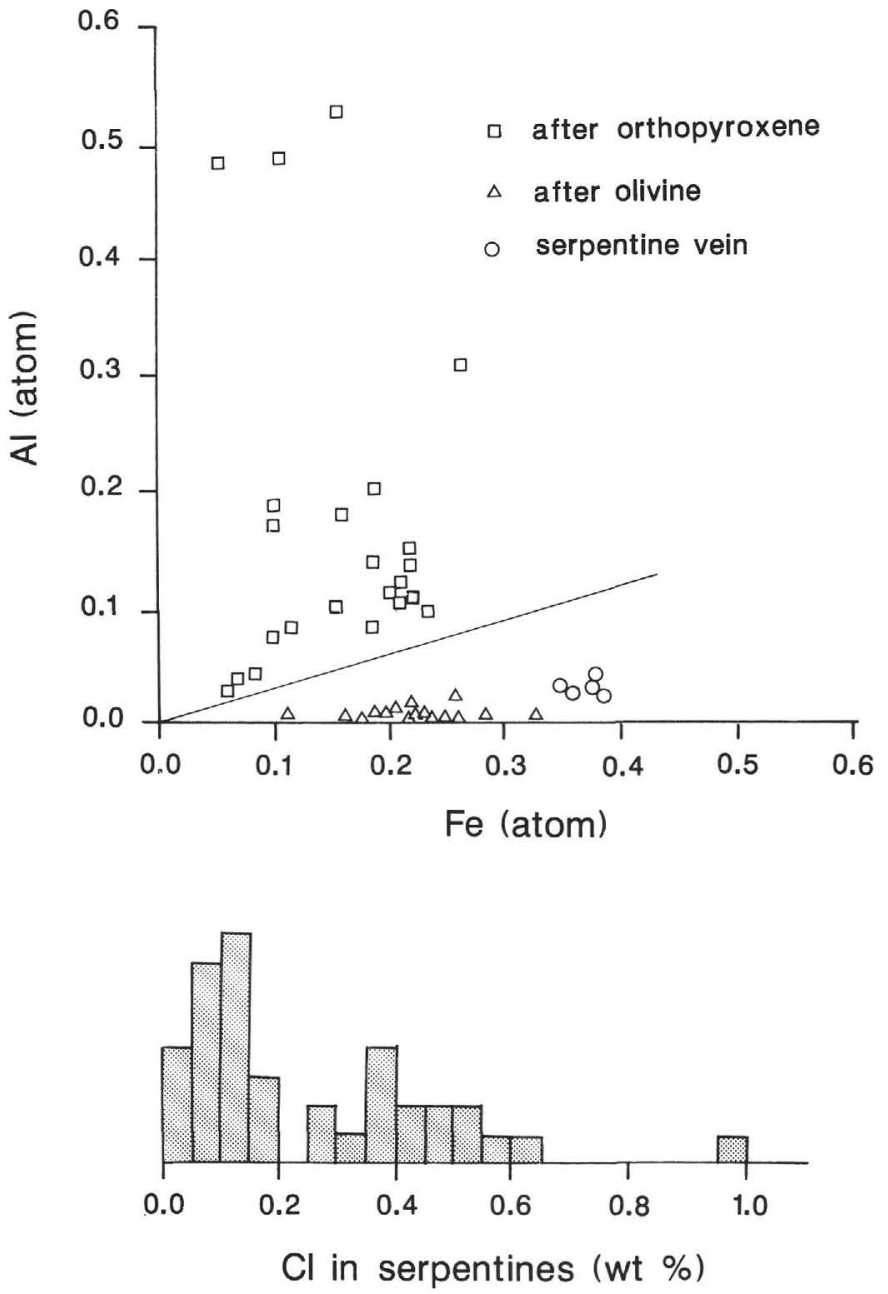

Figure 3. Serpentine compositions. A. A1 vs. Fe diagram. B. Chlorine content.

lite and greenschist facies (Evans, 1982). They probably formed at a temperature decreasing from $750^{\circ}$ to $350^{\circ} \mathrm{C}$. Development of these amphiboles requires water, which can be supplied either by destabilization of primary pargasite or, more likely, by introduction of water during uplift. The higher abundance of tremolite as compared to hornblende suggests increasing penetration of seawater with decreasing temperature, that is, with decreasing depth. But the major difference with St. Paul's rocks is that all of the amphiboles grew under static conditions. Some serpentine may have started growing with tremolite, but the bulk of the serpentinization occurred at lower temperatures $\left(<300^{\circ} \mathrm{C}\right)$, as evidenced by nature of the serpentine species (lizardite and chrysotile). Carbonates precipitated during a final stage, filling open fractures at much lower temperatures.

\section{OXYGEN AND HYDROGEN STABLE ISOTOPE DATA}

\section{Analytical Procedures}

Oxygen was extracted from silicate rocks by chlorine trifluoride (Borthwick and Harmon, 1982; J. R. O'Neil, pers. comm., 1985) and reacted with carbon to give $\mathrm{CO}_{2}$. In Table 3 , "silicates" refers to the whole rock, without calcite.

$\mathrm{CO}_{2}$ was extracted from calcite by $100 \% \mathrm{H}_{3} \mathrm{PO}_{4}$ at $25^{\circ} \mathrm{C}$ (McCrea, 1954).
Hydrogen, extracted mainly in the $\mathrm{H}_{2} \mathrm{O}$ form by fusion in an induction furnace, was obtained by reduction on hot uranium metal (Bigeleisen et al., 1952). The hydrogen yield was manometrically measured for precise determination of $\mathrm{H}_{2} \mathrm{O}^{+}$contents.

$\mathrm{CO}_{2}$ and $\mathrm{H}_{2}$ were run on a mass spectrometer to give ${ }^{18} \mathrm{O} /{ }^{16} \mathrm{O},{ }^{13} \mathrm{C} /$ ${ }^{12} \mathrm{C}$, and $\mathrm{D} / \mathrm{H}$ ratios.

The isotopic composition of a sample is given as

$$
\delta_{\text {sample }}=\left(\mathrm{R}_{\text {sample }} / \mathrm{R}_{\text {std }}-1\right) \times 1000,
$$

where $\mathrm{R}$ is ${ }^{18} \mathrm{O} /{ }^{16} \mathrm{O},{ }^{13} \mathrm{C} /{ }^{12} \mathrm{C}$, and $\mathrm{D} / \mathrm{H}$, and the standard is SMOW for oxygen and hydrogen and PDB for carbon ( $\delta$ values are expressed per mil).

Clinopyroxene crystals were picked under a binocular lens. The isotopic data are given in Table 3 and plotted in Figure 4.

\section{Serpentine}

The whole-rock $\mathrm{H}_{2} \mathrm{O}^{+}$contents $(>6.2 \mathrm{wt} \%$ ) show that these rocks are almost completely hydrated into serpentine materials (lizardite or chrysotile with minor amounts of magnetite), although they still contain scarce fresh primary phases (clinopyroxene and orthopyroxene). Because these relicts and secondary magnetite are present only in small amounts, the $\delta^{18} \mathrm{O}_{\mathrm{Si}}$ and $\delta \mathrm{D}_{\mathrm{wr}}$ are considered to be virtually those of the serpentines $\left(\delta^{18} \mathrm{O}\right.$ and $\delta \mathrm{D}$ mean values are about 10.3 and -75 , respectively). The serpentine data from Table 3 are shown in Figure 4, along with oceanic values from previous work (Wenner and Taylor, 1973; Sheppard, 1980; Bonatti et al., 1980, 1984).

As discussed by Sakai and Tsutsumi (1978), the interpretation of the oceanic serpentine's $\delta \mathrm{D}$ presents a problem depending on which serpentine-water hydrogen fractionation curves are used. Using a magmatic water-seawater mixture (ratio $\geq 1 / 1$ ), a high-temperature origin $\left(\mathrm{T} \geq 300^{\circ} \mathrm{C}\right.$ ) can be inferred (as for the experimental one of Sakai and Tsutsumi, 1978), whereas a lowtemperature origin $\left(\mathrm{T} \leq 250^{\circ} \mathrm{C}\right)$ from seawater can be deduced on the basis of the empirical calibration of Wenner and Taylor (1973).

This contrast is also displayed by the Hole 637A serpentines, which plot (Fig. 4) at the high $\delta^{18} \mathrm{O}$-low $\delta \mathrm{D}$ end of the oceanic serpentine field and below the low-temperature side of the curve that represents serpentine in isotopic equilibrium with seawater $(\delta \mathrm{D}=0)$, as suggested by Wenner and Taylor $(1971,1973)$. However, according to the experimental serpentine-water hydrogen curve of Sakai and Tsutsumi (1978), the $\delta$ D's of these serpentines would be permissive of magmatic or metamorphic fluids instead of seawater ( $\delta \mathrm{D}$ between -45 and -95 ) at a temperature between $500^{\circ}$ and $300^{\circ} \mathrm{C}$.

Nevertheless, Sakai and Tsutsumi (1978) have shown that kinetic effects on hydrogen isotopic fractionation can occur during the formation of serpentine and can explain the $\delta \mathrm{D}$ of the oceanic serpentines in terms of a low-temperature origin from seawater alteration. In addition, their experimental data show that serpentine (chrysotile) quickly exchanges its hydrogen isotopes with water, even at a low temperature $\left(\approx 100^{\circ} \mathrm{C}\right)$, and therefore, that preservation of the hydrogen kinetic fractionation and the high-temperature $\delta \mathrm{D}$ from later exchange with fluids seems unlikely. Hence, we consider that the $\delta \mathrm{D}$ 's of the serpentine are not conclusive for the nature of the serpentinizing fluids because they were probably acquired at low temperature $\left(\leq 100^{\circ} \mathrm{C}\right)$, which freezes the hydrogen composition of the serpentines.

The serpentine-water oxygen fractionation curve has not yet been experimentally determined, but Wenner and Taylor (1971) have suggested that it could be similar to that of the chlorite-water oxygen fractionation curve. Accordingly, they have estimated temperatures of serpentine formation from the serpentine-magnetite oxygen fractionation. The inferred temperatures are in the 
Table 3. ${ }^{16} \mathrm{O} /{ }^{18} \mathrm{O},{ }^{13} \mathrm{C} /{ }^{12} \mathrm{C}$, and $\mathrm{D} / \mathrm{H}$ analyses of Hole $637 \mathrm{~A}$ peridotites.

\begin{tabular}{|c|c|c|c|c|c|c|c|}
\hline \multirow[b]{2}{*}{ Sample } & \multicolumn{3}{|c|}{ Calcite } & \multicolumn{2}{|c|}{ Silicate } & \multicolumn{2}{|c|}{ Whole rock } \\
\hline & $\delta^{13} \mathrm{C}$ & $\delta^{18} \mathrm{C}$ & $\begin{array}{c}\mathrm{CaCO}_{3} \\
(\mathrm{wt} \%)\end{array}$ & $\delta^{18} \mathrm{O}$ & $\delta^{18} \mathrm{O} \mathrm{cpx}$ & $\delta \mathrm{D}_{\mathrm{wr}}$ & $\begin{array}{l}\mathrm{H}_{2} \mathrm{O}^{+} \\
\left(w \mathrm{wt}^{\circ}\right)\end{array}$ \\
\hline $103-637 \mathrm{~A}-26 \mathrm{R}-3,31-33 \mathrm{~cm}$ & 1.1 & 31.4 & 30 & ${ }^{a} 10.7$ & & -70 & 6.2 \\
\hline $26 \mathrm{R}-3,8-11 \mathrm{~cm}$ & 1.8 & 30.9 & 20.5 & ${ }_{8} 8.9$ & & -85 & 9.3 \\
\hline $26 \mathrm{R}-1,55-58 \mathrm{~cm}$ & 0.3 & 31.5 & 18.3 & ${ }^{\mathrm{a}} 10.1$ & & -75 & 9.4 \\
\hline $25 \mathrm{R}-5,141-144 \mathrm{~cm}$ & & & & ${ }^{\mathrm{a}} 11.5$ & 6.3 & -75 & 12.0 \\
\hline $25 \mathrm{R}-5,141-144 \mathrm{~cm}$ & -9.2 & 21.6 & 0.03 & 11.7 & & & \\
\hline $27 \mathrm{R}-3,29-32 \mathrm{~cm}$ & -4.5 & 34.7 & 0.04 & & 6.2 & & \\
\hline $27 \mathrm{R}-3,46-50 \mathrm{~cm}$ & & & & & 6.5 & & \\
\hline
\end{tabular}

${ }^{\text {a }}$ Calcite removed by gentle $\mathrm{HCl}$ attack.

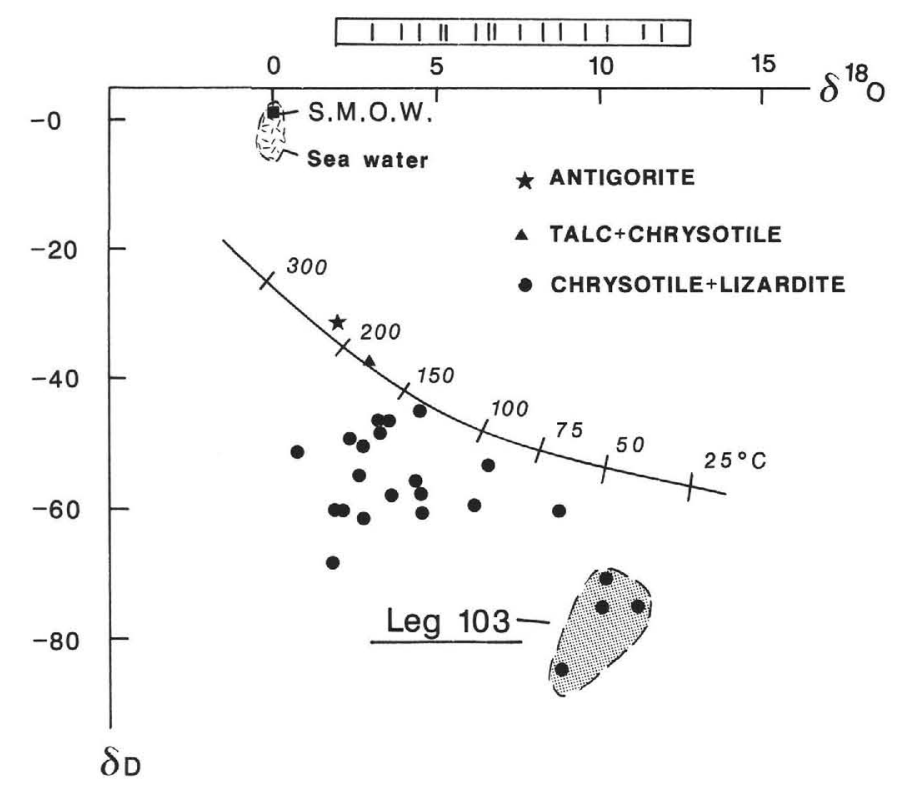

Figure $4 . \delta^{18} \mathrm{O}$ vs. $\delta \mathrm{D}$ for dredge or core samples of oceanic serpentines (Hole 637A peridotites, ODP Leg 103, this study; Wenner and Taylor, 1973; Sheppard, 1980). The distribution of serpentinite $\delta^{18} \mathrm{O}$ analyzed by Bonatti et al. (1980) is outside this diagram. The curve represents serpentine in equilibrium with seawater at temperatures less than $300^{\circ} \mathrm{C}$, according to Wenner and Taylor (1973) and Sheppard (1980).

range of $200^{\circ}$ to $50^{\circ} \mathrm{C}$ for the lizardite + chrysotile materials of the oceanic ultramafic rocks. They are compatible with those that would be expected if seawater was involved during the serpentinization processes (Wenner and Taylor, 1973) and range in the stability field of these serpentines (Moody, 1976).

The position of the Hole 637A serpentines on Figure 4 suggests a similar low-temperature origin (around $50^{\circ} \mathrm{C}$ ), in agreement with the lizardite-chrysotile nature of these serpentines.

To determine if these serpentines could have formed at high temperature but have subsequently frozen their oxygen isotopic composition at low temperature, we have analyzed some remaining clinopyroxenes. The $\delta^{18} \mathrm{O}$ of clinopyroxene is known to be rather insensitive with respect to hydrothermal exchange unless the hydrothermal interaction occurs at high temperature (above $400^{\circ} \mathrm{C}$; Taylor and Forester, 1971; Gregory and Taylor, 1981); therefore, it is suitable for tracking a high-temperature hydrothermal event. The clinopyroxene $\delta^{18} \mathrm{O}$ values (around 6.3) are a little enriched in ${ }^{18} \mathrm{O}$ relative to the clinopyroxene $\delta^{18} \mathrm{O}$ mean value from mantle mafic-ultramafic materials $\left(\delta^{18} \mathrm{O}=5.7\right.$ \pm 0.2 ; Taylor, 1968; Javoy, 1980). As proposed by Gregory and Taylor (1981), such a small increase of the pyroxene $\delta^{18} \mathrm{O}$ can be an isotopic memory of a high-temperature hydrothermal event, which is also evidenced by presence of secondary amphiboles.
Hence, it is conceivable that this high-temperature hydrothermal event could have produced some high-temperature serpentines (antigorite?) that subsequently recrystallized to lower temperature species.

\section{Calcite}

In the calcite-rich samples $\left(>10 \mathrm{wt} \%\right.$ ), calcite has $\delta^{13} \mathrm{C}$ values around +1.0 , close to those of seawater carbonates $(-1<$ $\delta^{13} \mathrm{C}<4$ ), and high $\delta^{18} \mathrm{O}$ values (above 30 ), which correspond to those of low-temperature marine carbonates. On the other hand, in the calcite-poor Samples 103-637A-25R-5, 141-145 cm, and 103-637A-27R-3, 29-32 cm, some $\mathrm{CO}_{2}$ with low $\delta^{13} \mathrm{C}(-9.2$ and -4.5 , respectively) is released by the $\mathrm{H}_{3} \mathrm{PO}_{4}$ procedure. These low $\delta^{13} \mathrm{C}$ values can indicate a contribution of low-concentration light carbon from the mafic-ultramafic material of the oceanic crust $\left(-6<\delta^{13} \mathrm{C}<-20\right.$; Pineau et al., 1976; Pineau and Javoy, 1983) as has been shown in ophiolite calcite-poor samples (Javoy and Fouillac, 1980; Stakes and O'Neil, 1982, Cocker et al., 1982).

This difference, inferred from the $\delta^{13} \mathrm{C}$ of the calcite, points out the existence of two alteration media. The first one, where carbon species are dominated by seawater carbonates, is open to low-temperature seawater circulation and probably matches the veins and the cracks. The second one, with lighter $\delta^{13} \mathrm{C}$, seems more protected from seawater circulation. As proposed by Barnes and O'Neil (1969), the low- $\delta^{13} \mathrm{C} \mathrm{CO}_{2}$ can correspond to calcites formed with the calcium lost from peridotites during serpentinization.

Assuming that the calcite from the veins and the cracks has formed in equilibrium with seawater, we infer, from the calcitewater fractionation geothermometer (O'Neil et al., 1969), temperatures around $10^{\circ} \mathrm{C}$ (i.e., close to that of bottom seawater temperatures $\approx 2^{\circ} \mathrm{C}$ ).

\section{DISCUSSION AND CONCLUSIONS}

On the basis of our petrologic and stable isotopic data recorded for Hole 637A peridotites, several stages of hydrous mineral crystallization can be defined:

1. Formation of Ti- and Cr-rich pargasites at high temperature $\left(800^{\circ}-900^{\circ} \mathrm{C}\right)$. From textural data, we can state that these amphiboles probably formed after the mylonitization of the peridotites, which occurred at a similar temperature $\left(1000^{\circ}-850^{\circ} \mathrm{C}\right)$ and under low pressure $(<0.2 \mathrm{GPa}$ ) (Girardeau et al., this volume). These amphiboles are not in equilibrium with the coexisting Ti-rich clinopyroxenes and consequently, probably developed by interaction with a metasomatic $\mathrm{Na}$ - and Ti-rich fluid, or with a magma.

2. Crystallization of hornblendes to tremolites under static conditions. The amphibole compositions indicate temperatures decreasing from $750^{\circ}$ to $350^{\circ} \mathrm{C}$. Interaction with a fluid phase was necessary to form the amphiboles, and we assume that at least small amounts of water (seawater?) started to penetrate the 
peridotites at this stage; this can explain the small ${ }^{18} \mathrm{O}$ shifts of the clinopyroxenes. Serpentinization also may have started simultaneously and produced antigorite. However, this mineral has not been found; if it ever did form, it has been either lost during the drilling process or recrystallized to lower temperature species.

3. Complete destablization of olivine into a lizardite-chrysotile \pm magnetite assemblage. Most serpentinization occurred under static conditions, as evidenced by the preservation of the detailed high-temperature deformation textures imprinted within the peridotite (Girardeau et al., this volume). Only a few late, brittle fractures are filled, with some serpentine and mostly by calcite. The mineral species (chrysotile and lizardite) are stable under a wide range of temperatures, from $300^{\circ}$ to $0^{\circ} \mathrm{C}$ (Evans et al., 1976). If we consider that the serpentine formed in equilibrium with seawater, the stable isotope data suggest a low temperature (around $50^{\circ} \mathrm{C}$ ), which is consistent with a late serpentinzation process occurring close to the sea bottom. Because the serpentinization reaction is exothermic, the reaction could have started with seawater at sea-bottom temperature (Fyfe and Lonsdale, 1981). It could have been contemporaneous with the late fracturing event, as suggested by the fact that the scarce samples containing relicts of olivine (black rocks in hand specimen) are always the less fractured ones.

It is difficult to infer a late subsurface hypothesis if serpentinization occurred close to $300^{\circ} \mathrm{C}$. Indeed, temperatures up to $300^{\circ} \mathrm{C}$ are not expected when the peridotite ridge arrived at the sea bottom, except if it experienced extensive magmatic activity. This is not supported by the petrological data. If the bulk of the serpentinization occurred at depth, we should have observed a schistose serpentine shear zone that formed during the ascent of the ultramafic body. These shear zones do not exist in the samples studied, but they could have been obscured by the drilling process. Finally, the serpentines would have re-equilibrated their oxygen isotope ratios during the final emplacement. Therefore, we think that most of the serpentinization occurred close to the sea bottom. The example of Zarbargad Island, where peridotites are completely devoid of serpentine (but do contain hornblende and actinolite; C. Mével, unpubl. data), demonstrates that peridotite emplacement in the rift zone is not a consequence of serpentinization (Bonatti et al., 1981; Nicolas et al., 1987).

In any case, lower temperature ductile shear zones postdating the high-temperature shearing event (Girardeau et al., this volume) probably formed during the ascent of the Hole 637A peridotite. Such shear zones should exist at the contact between the peridotites and the overlying continental crustal rocks, although they have not been found at the top of the peridotite ridge. They possibly have been erased by erosion.

4. Precipitation in open fractures of calcite that locally pervasively impregnates the peridotites. Calcite precipitates from seawater at temperature around $10^{\circ} \mathrm{C}$. It is noted that the peridotites from Leg 103 do not display the late, very low-temperature mineral assemblage (clay minerals) observed in peridotite dredge samples (Boillot et al., 1980), probably because they were cored at depth.

\section{Conclusions}

Leg 103 peridotites were likely emplaced during the first stage of ocean formation (Boillot et al., 1980, 1985, 1987). This petrological study of secondary phases evidences a multistage static metamorphic evolution in the presence of fluids during the ascent of the peridotites, beginning with a discrete high-temperature $\left(800^{\circ}-900^{\circ} \mathrm{C}\right)$ event consecutive to the high-temperature $\left(1000^{\circ}-850^{\circ} \mathrm{C}\right)$ mylonitization of the peridotite. The pyroxenes were then destablized into amphiboles at decreasing temperatures $\left(750^{\circ}-350^{\circ} \mathrm{C}\right)$. The water supply necessary for the crystallization of secondary amphiboles was possibly seawater introduced within the peridotites at deep levels along normal faults crosscutting the brittle peridotite. The main serpentinization of the peridotite was produced at temperatures below $300^{\circ} \mathrm{C}$, possibly after the final emplacement of the peridotite in its present position. This indicates that the peridotite uplift is not directly linked to serpentinite buoyancy property. This is also true for the emplacement of the Zabargad peridotites, which are totally fresh (Bonatti et al., 1981, 1986; Nicolas et al., 1987), and raises the problem of subsurface mantle ascent during the rifting process.

\section{ACKNOWLEDGMENTS}

The authors thank M. Javoy and J.C.C. Mercier for helpful comments and $\mathrm{Ch}$. Godecaux and A. Michel for technical assistance. This work was supported by ATP GGO. This manuscript was reviewed by J. Lawrence, P. Michael, D. Wenner, and G. Boillot. This is IPGP contribution no. 1027 .

\section{REFERENCES}

Aumento, F., and Loubat, H., 1971. The Mid-Atlantic Ridge near $45^{\circ}$ S: serpentinized ultramafic intrusions. Can. J. Earth Sci., 18: 631-664.

Barnes, I., and O'Neil, J. R., 1969. The relationships between fluids in some fresh alpine-type ultramafics and possible modern serpentinization, western United States. Geol. Soc Am. Bull., 80:1947-1960.

Bertrand, P., and Mercier, J. C., 1983. Ultramafic xenoliths from Malaita, Solomon Islands: physical state of an oceanic lithospheric mantle. Terra Cognita, 3:121. (Abstract)

Bigeleisen, J., Perlan, M. L., and Prosser, H. C., 1952. Conversion of hydrogenic materials to hydrogen for isotopic analyses. Anal. Chem., 24:13-56.

Boillot, G., Grimaud, S., Mauffret, A., Mougenot, D., Komprobst, J., Mergoil-Daniel, J., and Torrent, C., 1980. Ocean-continent boundary off the Iberian margin: a serpentinite diapir west of the Galicia Bank. Earth Planet. Sci. Lett., 48:23-34.

Boillot, G., Recq. M., Winterer, E. L., Meyer, A. W., Applegate, J., Baltuck, M., Bergen, J. A., Comas, M., Davies, T. A., Dunham, K., Evans, C. A., Girardeau, J., Goldberg, D., Haggerty, J., Jansa, L. F., Johnson, J. A., Kasahara, J., Loreau, J.-P., Luna-Sierra, E., Moullade, M., Ogg, J., Sarti, M., Thurow, J., and Williamson, M., 1987. Tectonic denudation of the upper mantle along passive margins: a model based on drilling results (ODP Leg 103, western Galicia margin, Spain). Tectonophysics, 132:335-342.

Boillot, G., Winterer, E. L., Meyer, A.W., Applegate, J., Baltuck, M., Bergen, J. A., Comas, M., Davies, T. A., Dunham, K., Evans, C. A., Girardeau, J., Goldberg, D., Haggerty, J., Jansa, L. F., Johnson, J. A., Kasahara, J., Loreau, J.-P., Luna-Sierra, E., Moullade, M., Ogg, J., Sarti, M., Thurow, J., and Williamson, M., 1985. Preliminary results of Leg 103 of the drilling vessel Joides Resolution (ODP): sedimentation and distension during rifting of a passive margin; hypothesis of tectonic denudation of the mantle. $C . R$. Acad. Sci. Ser. 2, 301:627-631.

Bonatti, E., and Hamlyn, P. R., 1981. Oceanic rocks. In Emiliani, C. (Ed.), The Sea (Vol. 7): New York (Wiley), 241-283.

Bonatti, E., Hamlyn, R. E., and Ottonello, G., 1981. The upper mantle beneath a young oceanic rift: peridotites from the Island of $\mathrm{Za}$ bargad (Red Sea). Geology, 9:474-479.

Bonatti, E., Lawrence, J. R., Hamlyn, R. E., and Breger, D., 1980. Aragonite from deep sea ultramafic rocks. Geochim. Cosmochim. Acta, 44:1207-1214.

Bonatti, E., Lawrence, J. R., and Morandi, M., 1984. Serpentinization of oceanic peridotites: temperature dependence of mineralogy and boron content. Earth Planet. Sci. Lett., 70:88-94.

Bonatti, E., Ottonello, G., and Hamlyn, R. E., 1986. Peridotites from the island of Zabargad (St. John), Red Sea: petrology and geochemistry. J. Geophys. Res., 91:599-631.

Borthwick, J., and Harmon, R. S., 1982. A note regarding $\mathrm{ClF}_{3}$ as an alternative to $\mathrm{BrF}_{5}$ for oxygen isotope analysis. Geochim. Cosmochim. Acta, 46:1665-1668.

Cocker, J. D., Griffin, B. J., and Muehlenbachs, K., 1982. Oxygen and carbon isotope evidence for seawater-hydrothermal alteration of the Macquarie Island ophiolite. Earth Planet. Sci. Lett, 61:112-122.

Dawson, J. B., and Smith, J. V., 1982. Upper mantle amphiboles: a review. Mineral. Mag., 45:35-46. 
Evans, B. W., 1982. Amphiboles in metamorphosed ultramafic rocks. In Veblen, D. R., Ribbe, P. H. (Eds.), Amphiboles Review in Mineralogy: Mineral. Soc. Am. Spec. Pap., 9B:98-113.

Evans, B. W, Johannes, W., Oterdoom, H., and Trommsdorff, V., 1976. Stability of chrysotyle and antigorite in the serpentine multisystem. Schweiz. Mineral. Petrogr. Mitt., 56:79-93.

Fyfe, W. S., and Lonsdale, P., 1981. Ocean floor hydrothermal activity in oceanic rocks. In Emiliani, C. (Ed.), The Sea (Vol. 7): New York (Wiley), 589-638.

Gilbert, M. C., 1966. Synthesis and stability relations of hornblende ferropargasite. Am. J. Sci., 264:698-742.

Gregory, R. T., and Taylor, H. P., Jr., 1981. An oxygen isotope profile in a section of Cretaceous oceanic crust, Samail ophiolite, Oman: evidence for $\delta^{18} \mathrm{O}$ buffering of the oceans by deep ( $>5 \mathrm{~km}$ ) sea-water hydrothermal circulation at mid-oceanic ridges. J. Geophys. Res., 86: $2737-2755$.

Javoy, M., $1980 .{ }^{18} \mathrm{O} /{ }^{16} \mathrm{O}$ and $\mathrm{D} / \mathrm{H}$ ratios in high-temperature peridotites. In Allegre, C. J., and Aubouin, J. (Eds.), Associations Mafigues et Ultramafigues dans les Orogénes: Collog. Int. (CNRS), 272:800808.

Javoy, M., and Fouillac, A. M., 1980. Stable isotope ratios in DSDP Leg 51 basalts. In Donnelly, T., Francheteau, J., Bryan, W., Robinson, P., Flower, M., Salisbury, M., et al., Init. Repts. DSDP, 51, 52, 53, Pt. 2: Washington (U.S. Govt. Printing Office), 1153-1157.

Jenkins, D. M., 1983. Stability and composition relations of calci-amphiboles in ultramafic rocks. Contrib. Mineral. Petrol., 83:375-384.

Kimball, K. L., Spear, F. S., and Dick, H.J.B., 1985. High temperature alteration of abyssal utramafics from the Islas Orcadas fracture zone, South Atlantic. Contrib. Mineral. Petrol, 91:307-320.

McCrea, J. M., 1954. On the isotropic chemistry of carbonates and a paleotemperature scale. J. Chem. Phys., 18:849-857.

Melson, W. B., Hart, S. R., and Thomson, G., 1972. St. Paul's rocks equatorial Atlantic: petrogenesis, radiometric ages and implications on seafloor spreading. Mem. Geol. Soc. Am. 132:241-272.

Melson, W. B., Jaroosewich, E., Cifelli, R., 1967. St. Peter and St. Paul's rocks: a high temperature mantle-derived intrusion. Science, 155:1532-1535.

Michael, P. J., and Bonatti, E., 1985. Petrology of ultramafic rocks from Sites, 556, 558 and 560 in the North Atlantic. In Bougault, H., Cande, S. C., et al., Init. Repts. DSDP, 82: Washington (U.S. Govt. Printing Office), 523-528.

Moody, J. B., 1976. Serpentinization: a review. Lithos, 9:125-138.

Nicolas, A., Boudier, F., and Montigny, R., 1987. Structure of Zabargad Island and early rifting of the Red Sea. J. Geophys. Res., 92: 4610-4740.

Nixon, P. H., and Coleman, P. J., 1978. Garnet bearing lherzolites and discrete nodule suites from the Malaita Solomon Islands and their bearing on the nature and origin of the Ontong-Java Plateau. Austral. Soc. Explor. Geophys., 9:103-107.

O’Neil, J. R., Clayton, R. N., and Mayeda, T. K., 1969. Oxygen isotope fractionation in divalent metal carbonates. J. Chem. Phys., 51: $5547-5558$

Pineau, F., and Javoy, M., 1983. Carbon isotopes and concentrations in mid-oceanic ridge basalts. Earth Planet. Sci. Lett., 62:239-257.

Pineau, F., Javoy, M., and Bottinga, Y., $1976 .{ }^{13} \mathrm{C} /{ }^{12} \mathrm{C}$ ratios of rocks and inclusions in popping rocks of the Mid-Atlantic Ridge and their bearing on the problem of isotopic composition of deep-seated carbon. Earth Planet. Sci. Lett., 29:413-421.

Prichard, H. M., 1979. A petrographic study of the process of serpentinization in ophiolites and the oceanic crust. Contrib. Mineral. Petrol., 68:231-241.

Rucklidge, J. C., 1972. Chlorine in partially serpentinized dunite. Econ. Geol., 67:38-40.

Rucklidge, J. C., and Patterson, G. C., 1977. The role of chlorine in serpentinization. Contrib. Mineral. Petrol., 65:39-44.

Sakai, H., and Tsutsumi, M., 1978. D/H fractionation factors between serpentine and water at $100^{\circ} \mathrm{C}$ and $500^{\circ} \mathrm{C}$ and 2000 bars water pressure, and the D/H ratio of natural peridotites. Earth Planet. Sci. Lett., 40:231-242.

Sheppard, S.M.F., 1980. Isotope evidence for the origins of water during metamorphic processes in oceanic crust and ophiolite complexes. In Allegre, C. J., and Aubouin, J. (Eds.), Associations Mafiques et Ultramafiques dans les Orogénes: Collog. Int. CNRS, 272:135-147.

Stakes, D. S., and O'Neil, J. R., 1982. Mineralogy and stable isotope geochemistry of hydrothermally altered oceanic rocks. Earth Planet. Sci. Lett., 57:285-304.

Taylor, H. P., Jr., 1968. The oxygen isotope geochemistry of igneous rocks. Contrib. Mineral. Petrol., 19:1-71.

Taylor, H. P., Jr., and Forester, R., 1971. Low ${ }^{18} \mathrm{O}$ igneous rocks from the intrusive complex of Skye, Mull and Ardnamurchan, western Scotland. J. Petrol., 20:355-419.

Wenner, D. B., and Taylor, H. P., Jr., 1971. Temperatures of serpentinization of ultramafic rocks based on ${ }^{18} \mathrm{O} /{ }^{16} \mathrm{O}$ fractionation between coexisting serpentines and magnetite. Contrib. Mineral. Petrol., 32: 165-185.

, 1973. Oxygen and hydrogen isotope studies of the serpentinization of ultramafic rocks in oceanic environments and continental ophiolite complexes. Am. J. Sci., 273:207-239.

Date of initial receipt: 23 March 1987

Date of acceptance: 2 February 1988

Ms 103B-136 


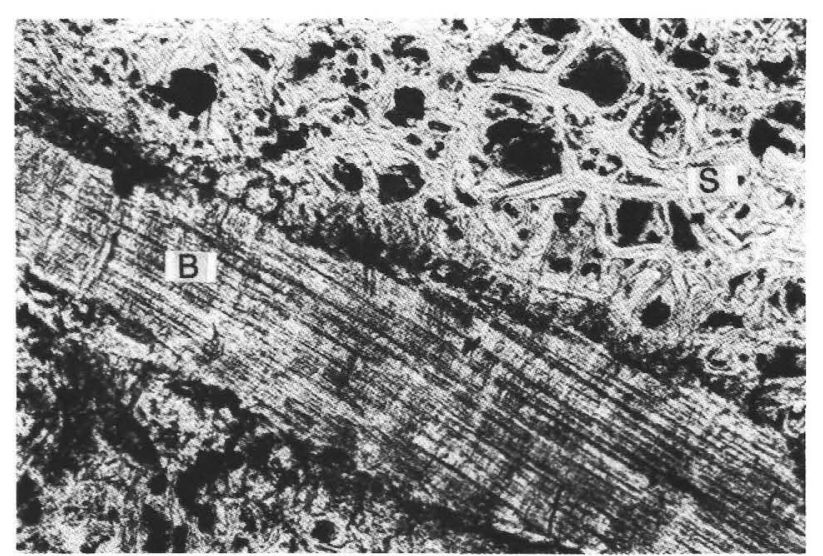

1

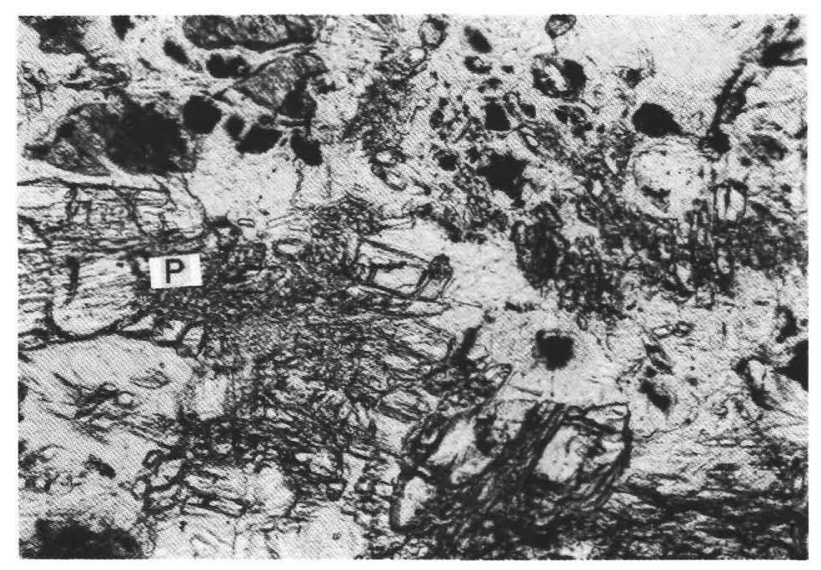

3

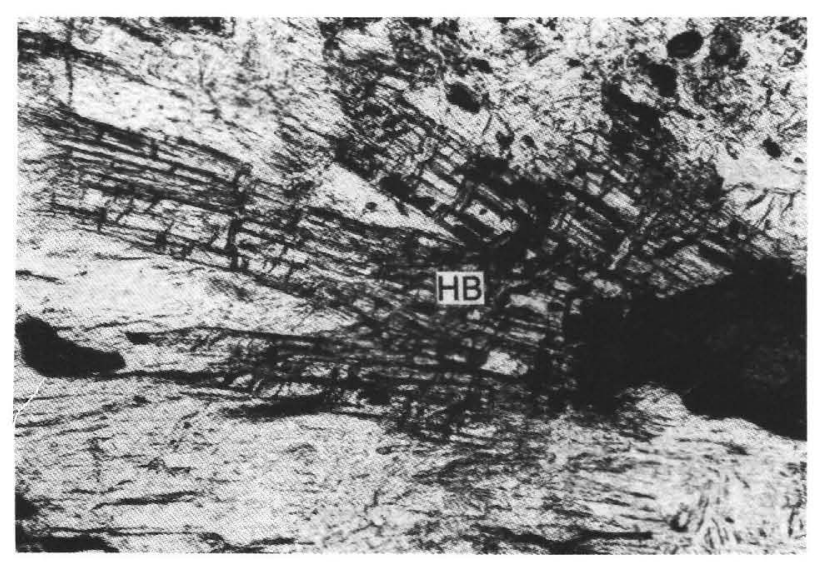

5

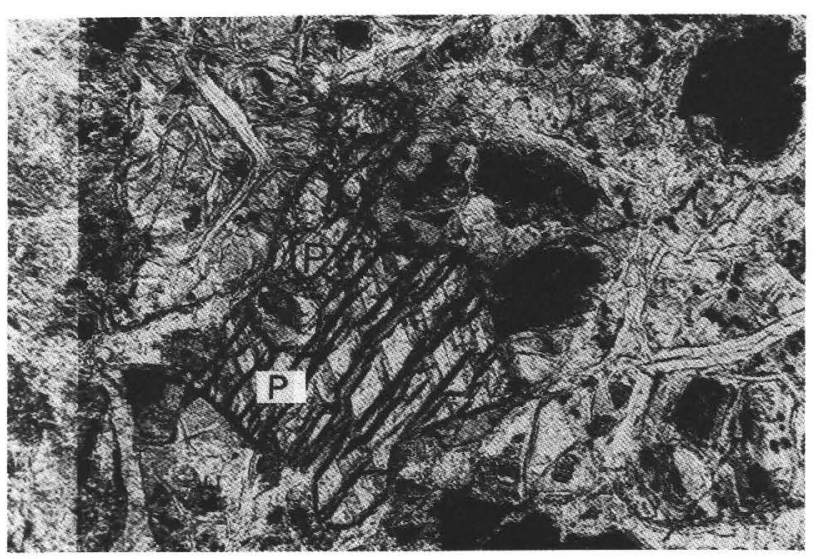

2

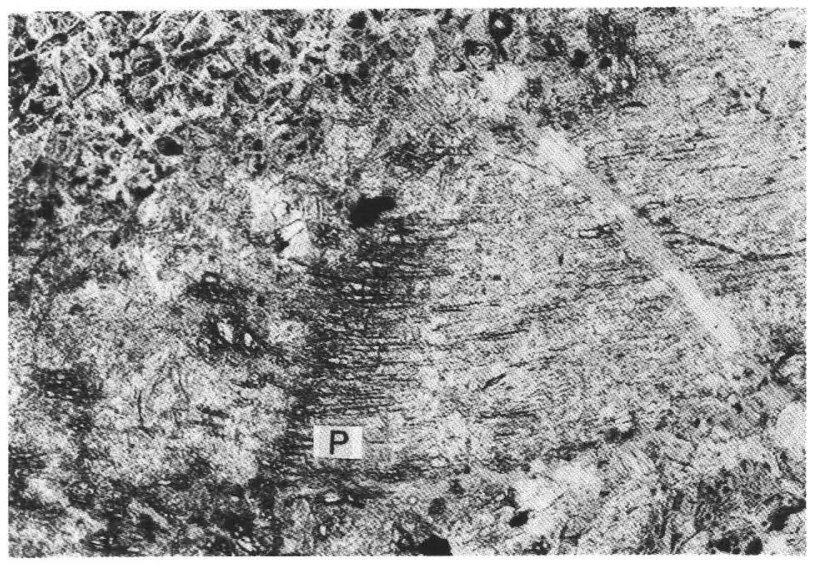

4

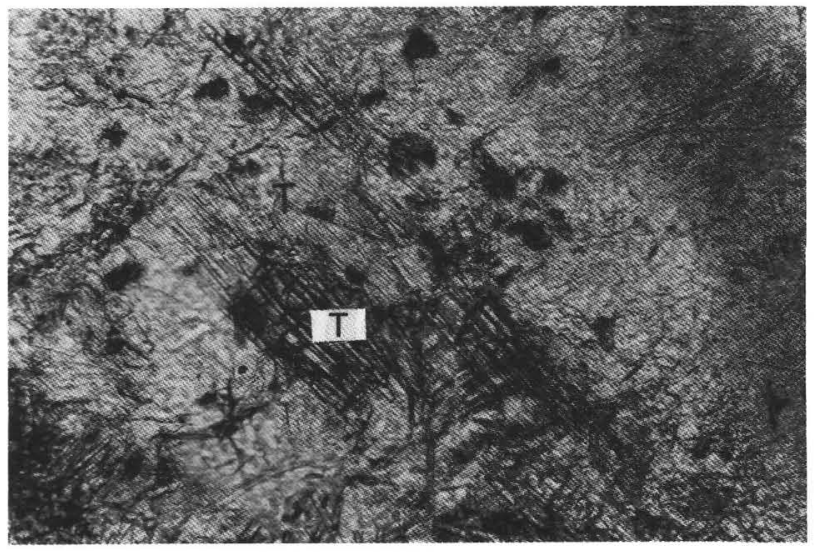

6

Plate 1. Photomicrographs of secondary hydrous products of Hole 637A peridotites. Parallel nicols. Bars represents $30 \mu \mathrm{m}$ 1. Textural difference between fibrous bastite (B) after orthopyroxene and mesh texture serpentine (S) after olivine (Sample 103-637A-27R-5, 18-23 cm). 2. Large individual crystal of pargasite (P) from Sample 103-637A-26R-4, 67-69 cm. 3. Tabular pargasite (P) crystals from Sample 103-637A-26R-1, 55-58 cm. 4. Elongate pargasite $(P)$ crystals growing from clinopyroxene exsolution lamellae in a bastitized orthopyroxene crystal (Sample 103-637A-26R-4, 67$69 \mathrm{~cm}$ ). 5. Hornblende (HB) needles growing on a spinel grain (dark crystal) in Sample 103-637A-27-2, 20-26 cm. 6. Fine tremolite (T) needles from Sample 103-637A-27R-3, 21-24 cm. 